\title{
Pentecostalisation. A Catholic Voice in the Debate
}

\author{
Przemysław Sawa
}

check for updates

Citation: Sawa, Przemysław. 2021. Pentecostalisation. A Catholic Voice in the Debate. Religions 12: 623 https://doi.org/10.3390/rel12080623

Academic Editor: Simon Dein

Received: 13 July 2021

Accepted: 6 August 2021

Published: 10 August 2021

Publisher's Note: MDPI stays neutral with regard to jurisdictional claims in published maps and institutional affiliations.

Copyright: (C) 2021 by the author. Licensee MDPI, Basel, Switzerland This article is an open access article distributed under the terms and conditions of the Creative Commons Attribution (CC BY) license (https:// creativecommons.org/licenses/by/ $4.0 /)$.
Faculty of Theology, University of Silesia, 40-007 Katowice, Poland; przemyslaw.sawa@us.edu.pl

\begin{abstract}
Pentecostalisation is one of several contentious issues in the Catholic Church. While charismatic experience is welcome and refreshing, it is also connected with various spiritual and pastoral abuses, which is very concerning. When set in the context of the new evangelization and the charismatic reality, people become open to a new type of ecumenism, namely an ecumenism relying on forms of living the faith, on permeating pious practices, singing, and literature. Some people may ask if this features an exchange of gifts or rather indicates the rise of a new hybrid form of Christianity. An analysis of how Pentecostal spirituality has developed, particularly in the Catholic communities, does not lead to a conclusion that the new shape of spirituality poses a danger. Obviously, the theological and pastoral mistakes that do occur need to be corrected but a growth of the charismatic sphere that is integrated within a correct interpretation of faith and with the Tradition leads to a renewal of the Church and greater evangelization. The good outcomes of the catholic, i.e., universal, Charismatic Renewal cannot go unnoticed. In the increasingly secular world, it is only a return to the fundamental experience of apostolic evangelization and a testimony to a living faith of the baptized that may inspire non-believers to start looking for Jesus Christ. The Church cannot, therefore, be reduced to the hierarchical, sacramental, doctrinal, and moral reality only. It is necessary that the involvement of lay people increases and that they use charismatic gifts in a responsible and confident manner. For all this to happen, people must be open to new inspirations of the Holy Spirit.
\end{abstract}

Keywords: pentecostalisation; pentecostal spirituality; new ecumenism; charismatic movement; catholic-protestant dialogue

\section{Introduction}

There is a dispute among Catholics about the shape of the Church and ways of her renewal in the contemporary world. One of its aspects is the objections concerning protestantization, and in recent years also pentecostalisation, of the Catholic Church. In particular, an intense discussion has taken place among various groups in Poland. This may appear quite surprising given that it was in Poland where the new evangelization, relying to a considerable extent on the charismatic reality, was undertaken on a large scale. However, this matter refers in fact to the entire Catholic Church. It is not the new forms of spirituality, piety, and pastoral work that are actually under discussion, but rather the vision of the Church and the model of Christian life. That discourse is not only a pastoral but also a deeply dogmatic matter, one whose solution needs to be looked for in the Bible, the doctrine, spiritual theology, and social sciences, as only in this way can we correctly assess the renewed spirituality, evangelization, and pastoral work.

In view of the above, the presentation of the key points of the dispute will start with a definition of the somewhat ambiguous term 'pentecostalisation' and then with arguments "for and against" the Catholic Pentecostal spirituality. An identification of the components of a proper renewal of the Church seems to be the most important thing to do.

\section{Pentecostalisation-A Definition}

The broadly understood pentecostalisation should be placed in the context of Pentecostalism and Pentecostal spirituality. Precise definitions of the terms used herein may prevent the assessment of various spiritual phenomena from being unilateral and careless. 


\subsection{Pentecostalism/Pentecostal}

The first term to define is Pentecostalism, which is a part of a wider evangelical trend. Craig S. Keener makes a basic distinction saying that "the now-burgeoning scholarship on Pentecostalism in many major universities worldwide often speaks of Pentecostal in two ways: Pentecostal denominations (often with a capital P) and those who share a basic pentecostal experience or ethos (often with a small p), including charismatics, members of Third Wave churches, and others who emphasize similar spiritual experience" (Keener 2016, pp. 6-7). It is therefore of key importance to refer to the experience described in the Acts of the Apostles, especially the first Pentecost (Acts 2). In this context, Pentecostalism is a pandenominational reality which takes various forms. Naturally, all Christian traditions accept the action of the Holy Spirit but differently interpret the first Church's experience of Him and whether charismatic gifts are still valid.

However, in 21st century spirituality, the first understanding of 'Pentecostal' is basic and covers trends referring to charismatic experiences which are available to all believers. The Pentecostal awakening in the United States (see Synan 2006c, pp. 13-26; Owens 2006, pp. 53-85) and the necessity to establish new congregations, due to the existing communities not approving of the new phenomena (in particular glossolalia and prophecy), gave rise to the emergence of a Pentecostal tradition, which, having undergone subsequent waves of development, has become the fastest growing part of contemporary Christianity. Charismatic communities have also gained an important place in the Catholic Church (see Hocken 2006, pp. 251-77). Thus, the Pentecostal experience, understood as a new outpouring of the Holy Spirit on the baptized, as a charismatic renewal, and as new forms of piety (e.g., baptism in the Holy Spirit, praying in tongues, spontaneous worship or prayer for healing and deliverance), has become present in various Churches and church communities (see Synan 2006a, pp. 213-49; 2006b, pp. 179-212).

\subsection{Pentecostal Spirituality}

As mentioned above, Pentecostal spirituality should be looked upon both in the broad (pandenominational) and narrow senses (with respect to the Protestant or the so-called free Churches). However, certain common features can also be found, keeping in mind that spirituality is "a set of attitudes with intellectual, cognitive, emotional, evaluative and behavioural references" (Chmielewski 2002, p. 229). Pentecostal spirituality is therefore a part of the larger evangelical movement. Its key indicators are a focus on the Bible, more casual spreading of faith, radical Christocentrism (and focus on the Cross), convertism (consciously chosen faith and the related conversion), and commitment to evangelization. For Protestant evangelicalism, we should also mention the free formula of services, basically without liturgical forms. In the case of communities of evangelical provenance in the Catholic Church, they demonstrate themselves in spontaneous participation in various prayer meetings, outside of liturgy. To these elements, the Pentecostal realm adds acceptance of current gifts and charisms, including the extraordinary ones, and their active practise in prayer and service. The fundamental experience, besides conscious choice of faith, is baptism in the Holy Spirit, which should be understood as being filled with the Holy Spirit and God's love following the confession that Jesus Christ is one's personal Saviour and Lord, as well as a radical entry into the supernatural world. The phenomenon was aptly described by Derek Prince when he wrote that "the baptism in the Holy Spirit is a spiritual experience, a supernatural experience. In many cases, it is the first supernatural experience many Christians have ever had. As such, it ushers them into a new realm, and often, they are not at home in that realm. Among other things, it is a realm of spiritual conflict that most of them never knew before they were baptized in the Holy Spirit" (Prince 1985, p. 13). And although there are certain differences in how baptism in the Holy Spirit is understood by Protestant and Catholic communities, there are specific common consequences of that experience, across all denominations. These include biblical revival, greater focus on the prayer of praise, opening to the gifts of the Holy Spirit, change of life (including in the moral sense), and zeal for evangelization. At the same time, people 
are enabled to build living communities of believers. It becomes important to receive charisms, including extraordinary ones. It is worth remembering, following the thought of St. Thomas Aquinas, that these gifts "are an ordinary, though not universal, element in the life and functioning of the Church" (Gałuszka 2018, p. 94). A description of a Pentecostal spirituality in the broad sense should also recognise the following differences with respect to the Catholic or Reformation traditions: experience over doctrine, prayer and praise over the credo, references to life over theological deliberations, developing trust in God over the knowledge of catechism, and spontaneity over formulas. All these generate a new quality of spirituality.

\subsection{Pentecostalisation}

The term 'pentecostalisation' has many definitions, of which three are considered basic. The first one refers to the rapid development of Pentecostal communities in Latin America, Africa, and Asia. Not all of the newly emerging communities are part of a greater structure or form larger denominations; there are plenty of autonomous groups believing undetermined doctrine and relying on charismatic experience.

The term 'pentecostalisation' is also used to describe the processes of change in the forms of religious expression, life in relationship with God, the understanding of the truths of faith, and participation in Church life. This refers to various denominations. In practice, it means a new style of prayer (both individual and in group), new music (that goes beyond the boundaries of religious communities), glossolalia, prayer for healing, and deliverance (see Kobyliński 2016). These practices have secured a permanent place in the Catholic Church. A good example here is Poland, where over the last 20 years plenty of charismatic communities have appeared, healing masses have been organised, intercessory prayer groups have been formed, and a number of new evangelization initiatives have been undertaken, whether at parish, diocese, or national level.

Finally, 'pentecostalisation' means the broad Charismatic Renewal movement in the Catholic Church, which does not only cover classic charismatic groups, but also movements, communities and evangelization projects rooted in the Pentecostal experience (for example, the courses of St. Andrew School of Evangelization.). The significance of that trend was recognised by Pope Francis' decision to establish the Catholic Charismatic Renewal International Service (CHARIS), which is to serve as a meeting platform and to support various charismatic realms. Among the features that these numerous entities have in common are a reliance on baptism in the Holy Spirit and ecumenical openness ${ }^{1}$. This move by Pope Francis is definitely a turning point for the Catholic understanding of the charismatic and its presence in the Church's everyday life.

\section{Pros and Cons of Pentecostalisation}

The Pentecostal spirituality still arouses emotions, as a phenomenon, experience, and a theological issue. It is therefore worthwhile quoting the key arguments for and against it.

\subsection{Argument: Inappropriate Phenomena and Attitudes}

The first danger posed by pentecostalisation is the new manner of prayer it introduces, one based on charismatic experience, especially praying in tongues and a desire to see manifestations of the Holy Spirit's presence. Those who put forward this argument say that an expectation of such gifts and phenomena by all believers has no justification in the long history of the Church. Miracles, extraordinary signs and mysticism have always been present in the Church, but usually as an experience of only some believers who, in many cases, led very ascetic lives. They were understood as God's special gifts that enabled the gifted to undertake significant missions. In this interpretation, a charismatic experience is closely related to the sanctity of a given person. In the Pentecostal practice, on the other hand, it is claimed that charisms may be outpoured on all, which-according to some people-is unjustified and seems unnecessary. This opinion is in line with the cessationists' narrative that spiritual gifts ceased with the deaths of the Apostles and are unnecessary 
after God's word (the Bible) was written down and the Church structure (hierarchy, liturgy, piety, theology) was established. Consequently, the teaching that the Spirit's special gifts have continued to the present age (continuationism) and should be practised may-in their opinion-be considered an attack on the hitherto forms of Christian religiousness.

However, speaking of a new more expressive style of prayer, one should not focus exclusively on the external manifestations. There is a threat of excessive concentration on experience only, which becomes a sort of sola experientia in some communities. In this way, personal spiritual experience may be determining the entire religious and life experience. Also, any deeper reflection about the phenomena and truths of faith is moved aside, as one's own experience is considered most important and reviving. In this extreme approach, the subjective aspect becomes a key matter with respect to faith, which eventually leads to individualism and inability to build a stable community of the baptized. It translates into absolutisation of one's own experience. ${ }^{2}$

Sometimes charismatic (Pentecostal) practices get distorted. For example, various sorts of abuse or manipulation connected with prayer for healing or deliverance may take place. The former is sometimes connected with excessive concentration on the expectation of healing, and during the prayer the hoped-for effect is sometimes announced too soon, which may be connected with strong emotions. It would of course be wrong to reject the gifts of understanding or prophesy, but there are groups of believers who do not care about examining healings, relying on medical evidence, or verifying whether the effect is permanent. In such cases, it may happen that various natural phenomena are considered supernatural and that psychomanipulation, hysteria, or trance are used, even if unconsciously (Kobyliński 2016, pp. 111-16). Furthermore, when the subjective experience becomes a final criterion of truth, it is just a step away from serious spiritual abuse. ${ }^{3}$ Such situations occur in communities that lack proper formation, especially biblical and doctrinal formation.

Pentecostalism is also criticised for the huge numbers of believers leaving the Catholic Church and joining various, sometimes not well defined, Pentecostal communities in Latin America. This is particularly evident in Brazil, which is now a focus of Pentecostal processes. That is why some people are raising the alarm showing that the Pentecostal practice in Catholic groups leads to denominational syncretism and eventually contributes to more and more believers leaving the Church to join Pentecostal or similar communities (see Pan-Amazonian Ecclesial Network 2019, pp. 28-26.); in Amazonia, approximately 43\% of people belong to such communities.

\subsection{Counterargument: Positive Effects of Charismatic Renewal}

Counterarguments to those presented above suggest that the broadly understood Pentecostal spirituality is a manifestation of the Holy Spirit's actual actions and a way of the Church's renewal. More than 50 years of the Catholic Charismatic Renewal's experience cannot simply be denied. That is why in his address to the Council of the International Catholic Charismatic Renewal Office, John Paul II confirmed that the realm was a particular gift of the Holy Spirit and did a lot of good, ${ }^{4}$ respecting the entire heritage of the Tradition. Most importantly, it is in line with the Church's nature: "In the history of the Church, the old and the new are always closely interwoven. The new grows out of the old, and the old finds a fuller expression in the new" (John 1994, no. 18).

Pentecostal spirituality brings sanctification and renewal of the Church, primarily through praise, thanksgiving, and intercession, leading to renewed evangelization (see John 1988a, p. 167). The new quality in spirituality manifests itself in biblical mentality; more conscious attitudes to the covenant of baptism; greater involvement of believers in the prayer, liturgy, and life of the Church; obedience to the bishops; and building a "culture of Pentecost" (John 2002). At the same time, it offers the enthusiasm of the faith, which is desired and authenticates evangelization, serving as a testimony of hope arising from the experience of God's love. Speaking to the Council of the International Catholic Charismatic Renewal Office on 11 December 1979, John Paul II said: "we say that the faith 
is a matter of the intelligence, and at times also of the heart, but this expressive dimension has been absent. This dimension of the faith was diminished, indeed inhibited ... " (Pesare 2001, p. 84). It is in fact the charismatic and evangelization communities that give the Church a lot of joy of the faith, seen not only as a way of life but also as a way to build an intense relationship with God. This helps to truly strengthen inner life. Therefore, Christian communities "must become genuine schools of prayer, where the meeting with Christ is expressed not just in imploring help but also in thanksgiving, praise, adoration, contemplation, listening, and ardent devotion, until the heart truly falls in love" (John 2001, no 33; see Congregation for the Doctrine of the Faith 1989, no 1-7). All this can be seen in various communities. ${ }^{5}$

\subsection{Common Objections: Theological Mistakes in Pentecostal Communities}

We cannot confine ourselves to a description of the phenomena only, because practice is connected with theological issues as well. Although both supporters and opponents of the Pentecostal spirituality can see various irregularities, they interpret them differently. One of the main objections concerns differences in how the truths of faith are understood, which may lead to redefinition of some points of the catechism.

The first aspect to consider is the lessened focus on theological reflection aimed at understanding faith, resulting from treating experience as the key criterion. At the same time, "it is intrinsic to faith that a believer desires to know better the One in whom he has put his faith, and to understand better what He has revealed; a more penetrating knowledge will in turn call forth a greater faith, increasingly set afire by love" (Catechism of the Catholic Church 1993, no. 158). It should, however, be said that there are charismatic communities in the Church that have solid spiritual and theological formation. A lot depends, therefore, on whether believers receive appropriate guidance.

Secondly, there is a danger of developing a spirituality focused on miracles and other extraordinary phenomena, which many people may view as a criterion of personal sanctity and God's presence in their lives. This refers in particular to the phenomenon of resting in the Spirit, which tends to be abused or even treated as a sign of openness to God. This is unacceptable from the point of view of the Catholic dogmatics, and of a sound sense of faith and the Church history, as extraordinary phenomena cannot be considered a standard. However, the fact that God makes his presence felt cannot be denied, as St. Thomas Aquinas pointed out "charisms are like heat, emitted by a flame and felt outside" (Gałuszka 2018, p. 91).

Thirdly, the postulate of the possibility of having a relationship with God and getting to know Him raises doubts, mainly because of the common expectation of prophesy and new forms of mysticism. ${ }^{6}$ It is difficult to find an error in this thesis though, as God is free in His actions and in distributing them at will to each individual (1 Cor 12,11b).

Fourthly, opponents of Pentecostal spirituality point to what, in their view, is a redefinition of various Christian, and especially Catholic, notions. For example, the term 'baptism in the Holy Spirit' has not appeared in the Church's teaching to indicate some kind of an act other than the sacrament of baptism, whereas it has become widely used in charismatic communities, which have been looking for a justification for it in those passages of the Acts of the Apostles that speak about outpouring of the Holy Spirit onto the first Christians. However, it cannot be denied that people do experience very personal revivals of faith and the power of the Holy Spirit. Was not the presentation of the integrity of the revealed truths and God's presence by Saint Ignatius of Loyola in the town of Manresa an analogic event? In this context, it is worth noting that St. Thomas Aquinas wrote about baptism with the blood, desire, or breath of the Holy Spirit, which can take place after baptism and be a form of renewal of the grace of the sacrament received. This understanding helps to capture the contemporary concept of baptism in the Holy Spirit in the Catholic sense (Gałuszka 2018, pp. 118-21).

Fifthly, it is still not right to preach prosperity theology (prosperity Gospel) the way it is preached by e.g., Kenneth Hagin, Robert Schuller, Robert Milton, and other followers 
of the Word of Faith movement. The starting point is Essek William Keyon's teaching of positive thinking and expectation of what a man in his faith considers as existing but not yet experienced. The above includes expectation of health, financial prosperity, comfort, security, and total freedom. All these are treated as signs of God's blessing. However, this view is verified by a proper reading of the New Testament (especially the theology of the Cross) and the life experience. Yet, certain valuable intuitions in the theses of the prosperity theology should also be noticed (e.g., the faith in the effectiveness of the word of $\left.\operatorname{God}^{7}\right)$, although the theory itself should be considered inappropriate for a healthy faith and spirituality.

Finally, in some Pentecostal circles wrong concepts of evil have developed. One of them is the theory of the so-called generational curse and intergenerational healing, according to which the sins of our ancestors are the source of various difficulties, including illnesses, in the lives of the next generations. The underlying reason is a literal and erroneous interpretation of biblical pericopes about evil persisting in families (e.g., $\mathrm{Nb} 14,18$; Ex 20,5; Ex 34,7; Dt 5,9), which is against the notion of individual responsibility (Ezk 18, 2-3) and the teaching of the Church. ${ }^{8}$ However, holding on to the theory leads to spiritual aberrations, such as blaming an evil on ancestors; the belief in determinism; lack of moral, spiritual, and mental development; a distorted picture of God (as inflicting punishment and seeking revenge); and developing the notion of curse. In this way a disturbing vision of the world and people's lives is created. ${ }^{9}$ It also translates into attaching excessive significance to demonic actions. An interest in bondage and possession, overexposure of prayer for deliverance, explaining difficulties as a direct intervention of evil spirits, as well as looking for various practices to defeat what is considered as Satan's action leads to piety (and spirituality) burdened with fear and makes believers apply Manichaean logic. Certainly, no one can deny that personal evil truly exists and acts, but inner life should be centred around God's love and Jesus' victory, as the Bible says:

we come through all these things triumphantly victorious, by the power of him who loved us. For I am certain of this: neither death nor life, nor angels, nor principalities, nothing already in existence and nothing still to come, nor any power, nor the heights nor the depths, nor any created thing whatever, will be able to come between us and the love of God, known to us in Christ Jesus our Lord.

(Rom 8,37-39)

Another disturbing argument is the more-or-less evident discontinuation of the forms of religious experience in the Catholic Church (hermeneutics of discontinuity). The roots of that phenomenon are considered to be in the changes that took place in the Church following the Second Vatican Council. Although in the late 1960s and 1970s a real disintegration of the Catholic Church's (but also other denominations') faith and identity began in many places, a number of abuses or various crises cannot be blamed on erroneous interpretations of the Council documents. In fact, the baptized were also affected by the overall social changes. It is therefore still justified to ask about the state of Catholics' inner life before the symbolic 1968 - was their faith something they inherited (considered a part of culture) or was it something they consciously chose based on their deep personal experience?

\subsection{Conversions-A Challenge to the Church}

Another aspect worth mentioning here are Catholics' conversions to Pentecostal communities. They cannot be explained with social causes only nor reduced to a temporary attractiveness of spontaneous spirituality. Many authors seem to ignore the Catholic Church's negligence in this respect. It is no understatement to say that rather than preaching the kerygma and caring for the believers' personal relationship with Christ, the Catholic ministry has long focused on religious practices and teaching the catechism, fostering values with an excessive concentration on moral theology, and an insufficient reliance on the Bible in the pastoral care and teaching of spirituality. 
In this context, many people are encouraged to convert by the radical lifestyle, the fundamentalism, the pietism, the sermons that offer answers to people's actual questions, the freedom of choice, feeling of belonging, and the identification with a community, with such small communities meeting the need to have a relationship (see Santagada 1995, pp. 17-25). The Holy See has also formulated the main reasons why Catholics decide to leave the Church. These include the feeling of being a part of a community, looking for answers to what happens in one's life, a holistic vision of life, looking for one's identity, the need to be noticed by others, looking for transcendence, spiritual guidance and vision, as well as the need to get engaged in various projects, especially missions. Therefore, the Church is challenged to care for believers' feeling of belonging, proper and continuous education, personal and integral approach, inculturation, changes in the area of prayer and cult (liturgy), and believers' participation in various (also leadership) structures (The Holy See 1986). All these expectations can be met in the Catholic Church, which should be more Bible- and mission-oriented, as well as more open to the contemporary world. A serious new evangelization will thus be a real remedy to the crisis connected with so many people leaving the Church.

\section{Catholic Direction}

Taking into account the two attitudes to the issue of pentecostalisation, it is necessary to make a thorough evaluation of the processes going on in the Catholic (Christian) spirituality and new forms of pastoral activity, especially those related to new evangelization. Therefore, relevant passages from the Bible, statements of the teaching office of the Church and the main lines of arguments about the manifestations of Pentecostalism, especially in the Catholic context, should be presented.

\subsection{Biblical Testimonies}

The Pentecost is the source of life for the Church. During the event, all those gathered in the Cenacle were filled with the Holy Spirit and received the gifts and charisms which made them ready to undertake Jesus' great mission. It was more than only a descent of the Paraclete. When speaking of the history of the first Church, the Acts of the Apostles mention various "small Pentecosts", such as after the release of the Apostles (Acts 4,31), during the mission in Samaria (Acts 8,17), or at the conversion of Saul (Acts 9,17). St. Paul's teaching is also relevant here, as he encouraged the baptized to open up to the Holy Spirit and desire charismatic gifts: About the gifts of the Spirit, brothers, I want you to be quite certain (1 Cor 12,1); Make love your aim; but be eager, too, for spiritual gifts, and especially for prophesying (1 Cor 14,1); So, my brothers, be eager to prophesy, and do not suppress the gift of speaking in tongues (1 Cor 14,39).

The validity of this apostolic message is particularly highlighted by representatives of the Pentecostal spirituality, which accepts the reality of God's Word (Heb 4,12) and miscellaneous acts of the Holy Spirit. So, supernatural phenomena, including miracles, need to be considered as being a normal part of the Church realm. To deny that would mean bereaving Christianity of its power. In fact, in its proper model, the Church's mission is to combine evangelization with the accompanying signs: they, going out, preached everywhere, the Lord working with them and confirming the word by the signs that accompanied it $(\mathrm{Mk} 16,20)$.

\subsection{Significant Impulses: From John XXIII to Francis}

A debate about new impulses for the Catholic spirituality should include references to certain important statements by popes and actions they took with respect to the Church structure. John Paul II directed the Church towards new evangelization, making it clear that it is not about undertaking the same evangelization efforts again but about evangelization that is renewed in its ardour, methods, and expression (see John 1983) in preaching the unchangeable Gospel (John 1993, no. 106). The same had been brought to people's attention by John XXIII, who, when opening the Second Vatican Council, said that the deposit of faith is one thing, and the way in which it is presented is another. ${ }^{10}$ The challenge remains to build one's faith 
on the basis of his or her personal choice of Jesus Christ, following an experience that He lives. Benedict XVI started Encyclical Deus caritas est with a reminder: "Being Christian is not the result of an ethical choice or a lofty idea, but the encounter with an event, a person, which gives life a new horizon and a decisive direction" (Benedict XVI 2005, no. 1).

New evangelization is more than only a pastoral trend, though-it has made its way to activities referring to the Church structure. On the solemnity of Saints Peter and Paul in 2010, Benedict XVI expressed his will to establish the Pontifical Council for Promoting the New Evangelization in response to the progressing secularization and positive effect of using new forms in proclaiming the values of the Gospel (Benedict XVI 2010b). On 21 September 2010, he issued 'Motu proprio' Ubicumque et semper (Benedict XVI 2010a), in which he defined the following objectives and responsibilities of the new dicastery: to promote the new evangelization, its forms and methods; to serve the particular Churches, especially in those territories where secularization is more obviously apparent; to examine in depth the theological and pastoral meaning of the new evangelization; to promote and to foster the study of the Papal Magisterium related to the new evangelization; to make known and to support initiatives linked to the new evangelization in various Church bodies (institutes of consecrated life and other communities); to study and to encourage the use of modern forms of communication; and to promote the use of the Catechism of the Catholic Church. The pope also decided to give the Council the competence for catechesis. In 'Motu proprio' Fides per doctrinam (Benedict XVI 2013), he laid down the following tasks of the Council: to promote the religious formation of the faithful; to issue norms meant to ensure that catechetical instruction is imparted in accordance with the Church's tradition; to ensure that catechetical formation is carried out with regard to its methods and aims, in accordance with the directives of the Church's magisterium; to grant the approval of the Holy See for catechisms and other writings pertaining to catechetical instruction, with the consent of the Congregation for the Doctrine of the Faith; to assist the offices for catechetics within Episcopal Conferences; to undertake initiatives pertaining to religious formation which are of an international nature; to coordinate various activities; and to provide assistance. Also, the International Council for Catechesis was transferred to the Pontifical Council for Promoting the New Evangelization. These decisions cannot be treated as of an organisational nature only. Benedict XVI made an indication that evangelization is a priority and should stimulate every area of the Church's activity (Saint Andrew School of Evangelisation-Germany 2007, pp. 8-9).

In his efforts to reform the Roman Curia, Pope Francis has emphasised the significance of evangelization and has planned to place the Dicastery for Evangelization in a central position in the structure of the Holy See. Another meaningful act was the establishment of the Catholic Charismatic Renewal International Service (CHARIS), a body playing an auxiliary role in various realms within the Church referring to the baptism in the Holy Spirit. In this way the richness of charismatic communities and movements, not only the classic Renewal in the Holy Spirit, was acknowledged. At the same time, the term 'baptism in the Holy Spirit' made its way to the official papal teaching to indicate the experience of faith revival through a new outpouring of the Holy Spirit. Moreover, Francis wants charismatic movements to share their experience with all Catholics and also in the ecumenical spirit. He expressed this will on the 50th anniversary of the Catholic Charismatic Renewal on 3 June 2017 in Rome. "To share baptism in the Holy Spirit with everyone in the Church, to praise the Lord unceasingly, to walk together with Christians of different Churches and Ecclesial Communities in prayer and activity on behalf of those in greatest need, to serve the poor and the sick" (Francis 2017). This task is truly a challenging one, as Christians are called not only to pray together but also to exchange spiritual gifts (ecumenism of the Spirit) and cooperate. These activities are particularly difficult to do when it comes to joint evangelization and preaching of the word of God. 


\subsection{The Charismatic in Bishops' Opinions}

It may also be worthwhile to go through what selected Conferences of Bishops have said about the matters concerned here. The Bishops of New Zealand stated the truth that getting to know Jesus personally is the essence of any renewal of the Church. "The soul of this renewal lies in enlivened personal relationship with Jesus Christ, and this is the work of the Holy Spirit (... ) It is essential, therefore, for a renewal of faith and life within the Church that individuals come to have a personal knowledge of the Risen Lord. On this there is no option" (The New Zealand Catholic Bishops' Conference 1981). The bishops of the United States spoke in a similar tone. When describing the baptism in the Holy Spirit, they said that it makes Jesus Christ "known and loved as Lord and Saviour, establishes or re-establishes an immediacy of relationship with all those persons of the Trinity (... ) There is new life and a new conscious awareness of God's power and presence" (The United States Conference of Catholic Bishops 1997; The Canadian Conference of Catholic Bishops 2003). This indicates that baptism in the Holy Spirit is an intimate experience of the third person of the Trinity and leads to a renewal of one's awareness of the baptismal identity; Canadian Bishops also make it very clear.

The Bishops of the Netherlands said that the Charismatic Renewal is a lifestyle in which the presence and activity of God, of the risen Christ and the Holy Spirit is directly experienced. It helps people open up to the descent of the Holy Spirit. It must also be acknowledged that the Renewal makes people get to know the Scripture better, joyously bear witness of the bond with Jesus, grow in personal and community prayer, popularize prayers for healing, forgiveness and deliverance, as well as create new communities (The Bishops of the Netherlands 1988). The Bishops of India, on the other hand, point to some specific needs of people, needs which do not seem to be adequately met in the usual church-setting: the need to belong to a warm fellowship, the need to participate in a way as disciples, the need to experience the power of the sacraments and become healed, the need to pray deeply with all their feelings, the need to discover the word of God, the need to be immersed in God's love, the need to experience Jesus' forgiveness, and the need to be empowered to witnesses to Jesus and be aglow with the Spirit.

In their letter to priests for the Maundy Thursday 2018, the Bishops of Poland emphasised the significance of the reality of the Church renewal: "Anyone who closely watches the contemporary Christianity will see the striking sign of the time- - the rising awareness of the Church as a work of the Holy Spirit. ( . . ) We can see the widespread longing for retreat and religious texts on it, we can see how much searched for are priests speaking about the works of the Holy Spirit or-in a greater degree-priests who can lead others into the experience of His power" (Polish Bishops' Conference 2018).

Individual conferences have also pointed to specific threats and challenges. The German Bishops mentioned an over-emphasis on feelings, a demonization of the world, a biblical fundamentalism, a religious complacency and an escape from reality (Theologischen Ausschuss der Charismatischen Erneuerung in der Katholischen Kirche 2007, pp. 39-41). The Bishops of Bombay spoke of an over-emphasis on healings and signs, a search for sensationalism and emotionalism, an over-insistence on glossolalia, an elitism, and a disrespect for people of other denominations (Pimenta et al. 1996). The voice of the bishops of Latin America is also important, as they experience proliferation of new, frequently sectarian, communities. The charismatic renewal has to, therefore, emphasise the role of sacraments and their connection with charisms, and should protect itself from biblical fundamentalism, emotionalism, and false ecumenism. It should also not neglect a sound worship of Virgin Mary (Encuentro Episcopal Latinoamericano en La Ceja 1987). The Canadian bishops' opinions on the subject are quite interesting, too. They emphasised the significance of prayer for healing, which should be a normal occurrence among the faithful but should not be introduced or take place within the existing Eucharistic celebration. They also spoke of the need for the formation of group leaders and all the baptized (The Canadian Conference of Catholic Bishops 2003). 


\subsection{The Voice of Cardinal Joseph Ratzinger}

The issue of pentecostalisation was also dealt with by Cardinal Joseph Ratzinger. He said that "the phenomenon of Pentecostalism, born in the Protestant world, now becamein a different way-indigenous to the Catholic Church in the form of the charismatic renewal movement. While on the one hand a wave of rationalism and a new enlightenment shook the Catholic Church and in various ways settled like hoarfrost on the life of faith, there was in the communities of the charismatic renewal, as in other movements which formed and perceived themselves as gifts of the Holy Spirit to the Church, a new experience of Pentecost, a joyful awareness of the Spirit's presence" (Ratzinger 2002, pp. 6-7). This refers to the renewal of the Church made by Vatican II and the gradual turning towards pneumatological considerations. At the same time, religious life did not remain indifferent to the influences of the broadened theological horizons. A good example here may be publications by Yves Congar (Ibid, pp. 5-7). As a result, the significance of the Holy Spirit is rediscovered today, not only in theory but also in practical life. And this happens within charismatic renewal communities (Messori and Joseph 2005, p. 136).

In the interview with Vittorio Messori, Ratzinger assessed the reality of the charismatic renewal, placing the experience in the context of the state of the Church. He said that "what is hopeful at the level of the universal Church - and that is happening right in the heart of the crisis of the Church in the Western worlds-is the rise of new movements which nobody had planned and which nobody has called into being, but which have sprung spontaneously from the inner vitality of the faith itself. What is manifested in them-albeit subdued-is something like a Pentecostal season in the Church" (Ibid, pp. 38-39). For the sake of clarity, the then Cardinal added that he meant charismatic movements. He also emphasised the great importance of new renewal movements and communities: "What is emerging here is a new generation of the Church which I am watching with a great hope. I find it marvellous that the Spirit is once more stronger than our programmes. In this sense the renewal, in a subdued but effective way, is afoot. Old forms that had run aground in self-contradiction and in the taste for negation are leaving the stage, and the new is making headway" (Ibid, p. 39). In the context of the renewal initiated by Vatican II and the current charismatic renewal, Ratzinger reminded that "what the New Testament describes, with reference to the charisms, as visible signs of the coming of the Spirit is no longer merely ancient, past history: this history is becoming a burning reality today" (Ibid, p. 136).

Ratzinger draws the readers' attention to certain border points, i.e., still valid guidelines for finding balance in one's Christian life. These include refraining from excessive exposure of the Holy Spirit, not implying that 'hierarchic' stands in opposition to 'charismatic,' keeping proper relation between objective faith and one's own experience (experience must be closely connected with dogmatic faith), not closing up in one small group only but being aware of one's belonging to the universal Church, and going through everything together with the Church; sentire cum Ecclesia (Ibid, p. 137). Cardinal Ratzinger clearly warned against superficial ecumenism, which may lead to a situation where "charismatic Catholic groups - not caring about preserving their identity - would unite uncritically with Pentecostals ( ... ) in the name of the 'Spirit' presented as an opposition to the institution. Catholic charismatic renewal groups must ( ... ) every time act in community with their bishops, also in order to avoid damage which always appears when the Scripture is taken out of its community context. Otherwise, we may see a specific sort of fundamentalism, esotericism and sectarianism" (Ibid).

\subsection{Proper Ecclesiology: Hierarchy and the Laity, Sacraments and Charisms}

The Catholic Church (as well as Eastern and Old Catholic Churches) values the service of ordained ministers, bishops, and presbyters, who participate in the anointing and mission of Jesus Christ ${ }^{11}$ and are signs "of the absolute priority and gratuitousness of the grace given to the Church by the risen Christ" (John 1992, no. 16). The shepherds of the baptized do their sacramental service in persona Christi capitis and are the first to bear responsibility for preaching the Word of God. This does not mean that they are placed 
above other people but rather that they work together with all believers, ${ }^{12}$ who share in the priesthood of the baptized.

However, limiting the Church's structure and pastoral work to the hierarchy only is contrary to the nature of a Christian community. It is necessary to accept and appreciate the charismatic dimension. That is why the Second Vatican Council unambiguously said: "It is not only through the sacraments and the ministries of the Church that the Holy Spirit sanctifies and leads the people of God and enriches it with virtues, but, "allotting his gifts to everyone according as He wills, He distributes special graces among the faithful of every rank. By these gifts He makes them fit and ready to undertake the various tasks and offices which contribute toward the renewal and building up of the Church" (II Vatican Council 1964, no. 22). Charismatic is not, of course, an alternative to but a natural complement of the hierarchy. And although a charismatic service needs to be discerned by the shepherds and exercised in close cooperation with them, bishops and presbyters cannot halt the laity's will to be actively engaged and use spiritual gifts. The gifts should therefore be appreciated and used, but only following their close examination. John Paul II expressed it aptly when he said: "The charisms are received in gratitude both on the part of the one who receives them, and also on the part of the entire Church. They are in fact a singularly rich source of grace for the vitality of the apostolate and for the holiness of the whole Body of Christ, provided that they be gifts that come truly from the Spirit and are exercised in full conformity with the authentic promptings of the Spirit. In this sense the discernment of charisms is always necessary" (John 1988b, no. 24). It is therefore difficult to notice a threat in using charisms, including the extraordinary ones, such as prophecy, healing, or deliverance. However, integrity of faith and Church is necessary, as the individual components are not contradictory. For spirituality and pastoral work to be sound and proper, there must exist all of the following elements: liturgy, hierarchy, community, charisms, theology and catechesis. The source of all that is the same-the Holy Spirit.

What would be harmful, on the other hand, is charismania, with its excessive focus on spectacular phenomena, constant expectation of healing, or inability to take decisions without first learning the words of wisdom and prophesies. It is also improper to recognize these phenomena, e.g., of resting in the Spirit, glossolalia or prophesy, as criteria of sanctity, as indications of a special relationship with God, or a position in a community. That logic may lead to various spiritual abuses and weakening of inner life, and the consequential infantilization of entire life.

\subsection{Proper Pastoral Care: Components of the Church's Renewal}

Pentecostalism may only be properly assessed if we keep in mind what is needed for a renewal of the Church. In order to stay united, the baptized must remain faithful to God's word and follow the teaching of the Magisterium of the Church and the Catholic theology, taking into account the always valid novelty of God's actions. It is also necessary that sceptics of the Pentecostal renewal be open to the freshness brought by the Holy Spirit, who inspires new solutions, including structural ones, in the Church. Additionally, Catholic charismatics should retain pastoral and spiritual reasonability, which manifests itself in obedience to bishops and fair evaluation of the new phenomena accompanying prayer and evangelization.

At the same time, everybody should care for proper renewal of the faith and structure of the Church. It is still challenging to move from faith that is only a cultural phenomenon to a conscious and voluntary choice of life with Jesus Christ thanks to the Holy Spirit. Such a decision can only be truly made following a personal experience of God's love and the true presence of the Risen Lord. The experience of spiritual awakening results in development of biblical mentality (appreciation of the Holy Scripture, daily prayer with biblical texts), new quality of prayer (in particular, a revival of praise), openness to gifts and charisms of the Holy Spirit, and a desire to evangelize and get involved in the Church's life. However, this kerygma cannot be the only aspect to focus on. A growth of faith requires a permanent, integral, and progressive catechesis, in its biblical, doctrinal, moral, spiritual, 
pastoral (evangelizing), human, and cultural dimensions. On the other hand, a renewal of the Church should be in accordance with the principle of continuity, which helps to open up to the signs of the times and the novelty created by the Holy Spirit, and should be rooted in the Tradition and the heritage of centuries. A renewal cannot be a revolution, as it is by nature an evolution, and in the first place it should be a conversion. Pope Francis calls for a pastoral conversion of the entire Church; a conversion which-if necessary-would involve a reform of the habits, styles, curricula, the Church language and structures, or even an abandonment of the common pastoral paths (Francis 2013, no. 27.33). The overriding objective should, however, be still clear-to help people create personal bonds with God through Jesus Christ and become more and more deeply involved in the Church. In this way, faith as a cultural phenomenon can change into faith of choice.

With all these things in mind, we can also emphasise the necessity to theologically deepen the ecclesiology in order to support contemporary Church, especially with respect to structure, discernment, and responsibility. We should also seek to obtain insights into charismatic phenomena, new forms of spirituality, theology of the laity or the place of Catholic movements, and communities. It all should translate into a broad vision of the Church, with Jesus Christ in the centre and with a clearly determined place for bishops, presbyters, and deacons, as well as consecrated and lay people, with respect for their proper tasks (confusion or opposition between these groups leads to a crisis of the Church). In addition, ecumenism (both theoretical and practical) remains a challenge, especially in the new areas of gift exchange between the Catholic charismatic spirituality and the Evangelic and Pentecostal.

\section{Conclusions}

The problem of pentecostalisation is multidimensional. In the first place, it is a natural reality for the life and mission of the Church, enabling her to open up to the Holy Spirit and accept the gifts and charisms that accompany evangelization. The Catholic Church needs a large-scale charismatic renewal, which does not mean abandonment of the entire heritage of faith whatsoever.

The novelty brought by the Holy Spirit must be integrated with the Tradition, teaching, and structure of the Church. It is necessary therefore that the hermeneutics of continuity is retained but in an active and responsible way. Pope Francis reminded us that sometimes it is necessary to go off the beaten track of living or teaching faith: "There are ecclesial structures which can hamper efforts at evangelization, yet even good structures are only helpful when there is a life constantly driving, sustaining and assessing them. ( . . ) In her ongoing discernment, the Church can also come to see that certain customs not directly connected to the heart of the Gospel, even some which have deep historical roots, are no longer properly understood and appreciated. Some of these customs may be beautiful, but they no longer serve as means of communicating the Gospel. We should not be afraid to re-examine them" (Francis 2013, no. 26.43).

Using charismatic gifts and undertaking various practices from the Pentecostal spirituality should always be in accordance with the Catholic theology. Proper formation of the lay faithful and the clergy is, therefore, necessary.

Taking proper measures centred around ecumenism is a challenge presented by contemporary times. What is of significant importance is the sharing of gifts, which can only take place where one has a personal relationship with Jesus, opens his or her heart and mind to the Holy Spirit, and cares for his or her own identity. Only then can a cooperation between denominations be successful.

The issue raised raises further questions and points to interesting research areas: How does evangelical (Pentecostal) theology influence Catholic theology? What terms should be used to properly express the main evangelical ideas in a Catholic spirit? What are the similarities and differences in traditional Catholic mysticism and charismatic experiences? How can spiritual gifts be exchanged without compromising confessional identity? 
Funding: Publication co-financed from funds allocated within the Research Excellence Initiative Programme of the University of Silesia in Katowice.

Institutional Review Board Statement: Not applicable.

Informed Consent Statement: Not applicable.

Conflicts of Interest: I alone am the author.

\section{Notes}

$1 \quad$ "The general objectives of CHARIS are: (a) to help deepen and promote the grace of baptism in the Holy Spirit throughout the Church; (b) to promote the exercise of charism not only in Catholic Charismatic Renewal but also in the whole Church; (c) To encourage the spiritual deepening and holiness of people who live the experience of baptism in the Holy Spirit; (d) To encourage commitment to evangelization, particularly through the new evangelization and the evangelization of culture, while respecting religious freedom; (e) to encourage cooperation between communities born from Catholic Charismatic Renewal, with a view to making the experience of particular communities available for the good of all; (f) to promote the ecumenical dimension of Catholic Charismatic Renewal and foster the commitment to serving the unity of all Christians; (g) to identify and promote specific topics that can help deepen the grace of Pentecost; $(\mathrm{h})$ to encourage networking and cooperation between realities within Catholic Charismatic Renewal in the areas of formation, evangelization etc.; (i) to promote service of the poor and social action through Catholic Charismatic Renewal; (j) to organize training and formation opportunities, according to the needs expressed by the General Assembly; (k) to enable clerics and the religious to deepen their experience of Catholic Charismatic Renewal with ecclesial movements that do not refer to this current of grace and with other Christian Churches and Communities, especially those living the experience of Pentecost; (1) to organise major events, colloquia, leaders gatherings, in order to share and exchange various experiences flowing from the Holy Spirit". (Catholic Charismatic Renewal International Service (CHARIS)).

$2 \quad$ Speaking of sanctity, Pope Francis aptly said: “Gnostics ( . . ) absolutize their own theories and force others to submit to their way of thinking" (Francis 2018, no. 39).

3 For example, it is highly irresponsible of people leading individual prayer for mental and emotional healing to announce that a given person has been healed, as a result of which the person would decide to stop taking the psychoactive drugs that he or she has been prescribed. A potential healing should obviously not be denied, but any decision to discontinue treatment should be taken by the doctor rather than the patient or any third person.

4 "... I willingly join you in giving praise to God for the many fruits which it has borne in the life of the Church. The emergence of the Renewal ( . . ) was a particular gift of the Holy Spirit to the Church" (John 1984a, p. 591).

5 “... recent years have been seeing a growth in the number of people who, in ever more widespread movements and groups, are giving first place to prayer and seeking in prayer a renewal of their spiritual life. This is a significant and comforting sign, for from this experience there is coming a real contribution to the revival of prayer among the faithful, who have been helped to gain a clearer idea of the Holy Spirit as he who inspires in hearts a profound yearning for holiness" (John 1986, no 65).

6 We can speak of a Pentecostal mysticism, focused on charismatic prayer, especially prayer in tongues, frequently accompanied by prophetic words and images, words of inspiration, or words of knowledge. See (Sawa 2017, pp. 156-76).

7 The following positive aspects can be mentioned here: positive vision of the world and life, bold prayer of petition, trust in God, linking faith with life, faith in the power of Jesus and God's word.

8 So every one of us will have to give an account of himself to God (Rom 14,12); "Sin, in the proper sense, is always a personal act, since it is an act of freedom on the part of an individual person and not properly of a group or community" (John 1984b, no. 16). Prayer for intergenerational healing has been explicitly forbidden by Polish bishops. See (Commission for the Doctrine of the Faith of the Polish Bishops' Conference 2015).

9 Various susceptibilities to specific evils or certain social links in this respect may of course remain in a human. "... in the baptized there remains concupiscence, or an incentive (to sin)" (The Council of Trent 1546, no. 5). "By virtue of human solidarity, which is as mysterious and intangible as it is real and concrete, each individual's sin in some way affects others. ( ...) a soul that lowers itself through sin drags down with itself the church and, in some way, the whole world" (John 1984b, no. 16).

10 “... occorre che questa dottrina certa ed immutabile, alla quale si deve prestare un assenso fedele, sia approfondita ed esposta secondo quanto è richiesto dai nostri tempi. Altro è infatti il deposito della Fede, cioè le verità che sono contenute nella nostra veneranda dottrina, altro è il modo con il quale esse sono annunziate, sempre però nello stesso senso e nella stessa accezione" (John XXIII 2012, p. 35).

11 “The priest's fundamental relationship is to Jesus Christ, head and shepherd. Indeed, the priest participates in a specific and authoritative way in the 'consecration/anointing' and in the 'mission' of Christ" (John 1992, no. 16).

12 Speaking about the service of the clergy, John Paul II said that a presbyter "cannot exercise his service on behalf of the Renewal unless and until he adopts a welcoming attitude towards it, based on the desire he shares with every Christian by baptism to grow in the gifts of the Holy Spirit" (John 1981). 


\section{References}

Benedict XVI. 2005. Encyclical. Deus Caritas est. Available online: http://www.vatican.va/content/benedict-xvi/en/encyclicals / documents/hf_ben-xvi_enc_20051225_deus-caritas-est.html (accessed on 15 January 2021).

Benedict XVI. 2010a. Apostolic Letter. Ubicumque et Semper. Available online: http://www.vatican.va/content/benedict-xvi/en/ apost_letters/documents/hf_ben-xvi_apl_20100921_ubicumque-et-semper.html (accessed on 15 January 2021).

Benedict XVI. 2010b. Homily (28 June 2010). Available online: https:/ /www.vatican.va/content/benedict-xvi/en/homilies/2010 /documents/hf_ben-xvi_hom_20100628_vespri-pietro-paolo.html (accessed on 24 April 2021).

Benedict XVI. 2013. Apostolic Letter. Fides per doctrinam. Available online: http://www.vatican.va/content/benedict-xvi/en/motu_ proprio/documents/hf_ben-xvi_motu-proprio_20130116_fides-per-doctrinam.html (accessed on 15 January 2021).

Catechism of the Catholic Church. 1993. Available online: https://www.vatican.va/archive/ENG0015/_INDEX.HTM (accessed on 30 January 2021).

Catholic Charismatic Renewal International Service (CHARIS). 2018. Statutes. Available online: https://www.charis.international/wpcontent/uploads/Statutes-CHARIS.pdf (accessed on 25 January 2021).

Chmielewski, Marek. 2002. Duchowość. In Leksykon duchowości katolickiej. Edited by Marek Chmielewski. Lublin-Kraków: Wydawnictwo "M", pp. 226-32.

Commission for the Doctrine of the Faith of the Polish Bishops' Conference. 2015. Grzech pokoleniowy i uzdrowienie międzypokoleniowe. Problemy teologiczne i pastoralne. Available online: http://www.episkopat.pl/grzech-pokoleniowy-i-uzdrowieniemiedzypokoleniowe-problemy-teologiczne-i-pastoralne (accessed on 31 December 2016).

Congregation for the Doctrine of the Faith. 1989. Letter to the Bishops of the Catholic Church on Some Aspects of Christian Meditation. Available online: http://www.vatican.va/roman_curia/congregations/cfaith/documents/rc_con_cfaith_doc_19891015_meditazionecristiana_en.html (accessed on 3 February 2021).

Encuentro Episcopal Latinoamericano en La Ceja. 1987. La Renovación espiritual católica. carismática. Available online: http:/ / old.iccrs.org/ public/img_catalogo/prodotti/DOCUMENTO_Encuentro-Episcopal-Latinoamericano_1987_Es.pdf (accessed on 3 June 2019).

Francis. 2013. Apostolic Exhortation. Evangelii Gaudium. Available online: http://www.vatican.va/content/francesco/en/apost_ exhortations/documents/papa-francesco_esortazione-ap_20131124_evangelii-gaudium.html (accessed on 18 January 2021).

Francis. 2017. Address during Pentecost Vigil of Prayer (3 June 2017). Available online: https: / /www.vatican.va / content/francesco / en/speeches/2017/june/documents/papa-francesco_20170603_veglia-pentecoste.html (accessed on 12 April 2021).

Francis. 2018. Apostolic Exhortation. Gaudete et Exsultate. Available online: https://www.vatican.va/content/francesco/en/apost_ exhortations /documents / papa-francesco_esortazione-ap_20180319_gaudete-et-exsultate.html\#An_intellect_without_God_ and_without_flesh (accessed on 30 January 2021).

Gałuszka, Tomasz. 2018. Odnowa w łasce. Teologia charyzmatów św. Tomasza z Akwinu. Kraków: Wydawnictwo Esprit.

Hocken, Peter. 2006. Katolicka odnowa charyzmatyczna. In Historia ruchu zielonoświatkowego i odnowy charyzmatycznej (orig. The century of the Holy Spirit: 100 Years of Pentecostal and Charismatic Reneval, 1901-2001). Edited by Vinson Synan. Translated by Maciej Wilkosz. Kraków-Szczecin: Instytut Wydawniczy Compassion, pp. 251-77.

II Vatican Council. 1964. Dogmatic Constitution on the Church. Lumen Gentium. Available online: http:/ /www.vatican.va/archive/ hist_councils/ii_vatican_council/documents/vat-ii_const_19641121_lumen-gentium_en.html (accessed on 15 January 2021).

John, Paul, II. 1981. Address to the Participants in the Fourth International Leaders' Conference of the Catholic Charismatic Renewal. Available online: https://www.vatican.va/content/john-paul-ii/en/speeches/1981/may/documents/hf_jp-ii_spe_19810507_rinnovamentocarismatico.html (accessed on 20 April 2021).

John, Paul, II. 1983. Discurso del Santo Padre Juan Pablo II a la Asamblea del CELAM. Available online: https://www.vatican.va/content/ john-paul-ii/es/speeches/1983/march/documents/hf_jp-ii_spe_19830309_assemblea-celam.html (accessed on 25 April 2021).

John, Paul, II. 1984a. Insegnamenti di Giovanni Paolo II, XV, 1, 1982. Vatican: Libreria Editrice Vaticana.

John, Paul, II. 1984b. Post-Synodal Apostolic Exhortation. Reconciliatio et paenitentia. Available online: http://www.vatican.va/ content/john-paul-ii/en/apost_exhortations/documents/hf_jp-ii_exh_02121984_reconciliatio-et-paenitentia.html (accessed on 30 January 2021).

John, Paul, II. 1986. Encyclical. Dominum et Vivificantem. Available online: http://www.vatican.va/content/john-paul-ii/en/ encyclicals/documents/hf_jp-ii_enc_18051986_dominum-et-vivificantem.html (accessed on 16 January 2021).

John, Paul, II. 1988a. Insegnamenti di Giovanni Paolo II. X,1. 1987. Vatican: Libreria Editrice Vaticana.

John, Paul, II. 1988b. Post-Synodal Apostolic Exhortation. Christifideles laici. Available online: http:/ /www.vatican.va/content/johnpaul-ii/en/apost_exhortations/documents/hf_jp-ii_exh_30121988_christifideles-laici.html (accessed on 19 January 2021).

John, Paul, II. 1992. Post-Synodal Apostolic Exhortation. Pastores dabo vobis. Available online: http:/ /www.vatican.va/content/johnpaul-ii/en/apost_exhortations/documents/hf_jp-ii_exh_25031992_pastores-dabo-vobis.html (accessed on 19 January 2021).

John, Paul, II. 1993. Encyclical. Veritatis Splendor. Available online: http:/ /www.vatican.va/content/john-paul-ii/en/encyclicals / documents/hf_jp-ii_enc_06081993_veritatis-splendor.html (accessed on 30 January 2021).

John, Paul, II. 1994. Apostolic Letter. Tertio Millennio Adveniente. Available online: http://www.vatican.va/content/john-paul-ii/en/ apost_letters/1994/documents/hf_jp-ii_apl_19941110_tertio-millennio-adveniente.html (accessed on 16 January 2021).

John, Paul, II. 2001. Apostolic Letter. Novo Millennio Ineunte. Available online: http://www.vatican.va/content/john-paul-ii/en/ apost_letters/2001/documents/hf_jp-ii_apl_20010106_novo-millennio-ineunte.html (accessed on 16 January 2021). 
John, Paul, II. 2002. Address to a Delegation of Members of the Renewal in the Holy Spirit Movement (Rome, 14 March 2002). Available online: https://www.vatican.va/content/john-paul-ii/en/speeches/2002/march/documents/hf_jp-ii_spe_20020314_rinnovamentospirito-santo.html (accessed on 20 April 2021).

John XXIII. 2012. Gaudet Mater Ecclesia. In Pontificio Consiglio per la promozione della Nuova Evangelizzazione 2012. Enchiridion della Nuova Evangelizzazione. Testi del Magistero pontificio e conciliare 1939-2012. Vatican: Libreria Editrice Vaticana, pp. 33-35.

Keener, Craig S. 2016. Spirit Hermeneutics. Reading Scripture at Light of Pentecost. Michigan: William B. Eerdmans Publishing Co. Kindle.

Kobyliński, Andrzej. 2016. The Global Pentecostalization of Christianity and Its Ethical Consequences. Chicago Studies 55: 100-20.

Messori, Vittorio, and Ratzinger Joseph. 2005. Raport o stanie wiary. Translated by Zyta Oryszyn, and Jan Chrapek. Marki: Wydawnictwo Michalineum.

Owens, Robert. 2006. Przebudzenie przy Azusa Street: Początek ruchu zielonoświątkowego w Ameryce. In Historia ruchu zielonoświatkowego i odnowy charyzmatycznej (orig. The century of the Holy Spirit: 100 Years of Pentecostal and Charismatic Reneval, 1901-2001). Edited by Vinson Synan. Translated by Maciej Wilkosz. Kraków-Szczecin: Instytut Wydawniczy Compassion, pp. 53-85.

Pan-Amazonian Ecclesial Network. 2019. Atlas Panamazónico. Available online: https://issuu.com/redrepam/docs/atlas_panamaz_ nico (accessed on 30 January 2021).

Pesare, Oreste, ed. 2001. Wtedy staną Piotr ... (Dz 2,14). Zbiór wypowiedzi papieskich skierowanych do Katolickiej Odnowy Charyzmatycznej od jej powstania do roku 2000. Kraków: Wydawnictwo "M".

Pimenta, Simon, Ferdinand Fonseca, Bosco Penha, and Thomas Dabre. 1996. Bishops' Pastoral Letter on the Charismatic Renewal. Available online: http://old.iccrs.org/public/img_catalogo/prodotti/PASTORAL-LETTER_Bishops-India_1996_En.pdf (accessed on 3 June 2019).

Polish Bishops' Conference. 2018. Siedem darów z Wieczernika. List biskupów polskich do kapłanów na Wielki Czwartek 2018 r., 3. Available online: www.episkopat.pl/siedem-darow-wieczernika-list-biskupow-polskich-do-kaplanow-na-wielki-czwartek2018-r/ (accessed on 27 March 2018).

Prince, Derek. 1985. Chrzest Duchem Świętym. Skrót wykładu wygłoszonego w City Temple w Londynie w 1964 roku. Translated by Magda Elektrowicz. Kraków: Towarzystwo Krzewienia Etyki Chrześcijańskiej.

Ratzinger, Joseph. 2002. Wprowadzenie do wydania w języku niemieckim. In Raniero Cantalamessa. Pieśń Ducha Świętego. Rozważania na temat Veni Creator. Translated by Marek Przeczewski. Warszawa: Wydawnictwo Sióstr Loretanek, pp. 6-7.

Saint Andrew School of Evangelisation-Germany. 2007. Pastoral Project Saint Andrew. Available online: http://www.icpe.org/ uploads/100-SA_pastoral_project_eng.pdf (accessed on 15 January 2021).

Santagada, Osvaldo D. 1995. Charakterystyka oraz sytuacja sekt i niezależnych grup religijnych. In Osvaldo D. Santagada and others. Wspólnoty kościelne, niezależne grupy religijne, sekty na przykładzie Ameryki Łacińskiej. Translated by Antoni Kajzerek. Warszawa: Verbinum. Wydawnictwo Księży Werbistów, pp. 17-25.

Sawa, Przemysław. 2017. Mistycyzm ewangelikalny-Źródła, podstawy, przejawy. Studia Teologii Dogmatycznej 3: 156-76. [CrossRef]

Synan, Vinson. 2006a. "Charyzmatycy"—odnowa w głównych denominacjach protestanckich. In Historia ruchu zielonoświątkowego $i$ odnowy charyzmatycznej (orig. The century of the Holy Spirit: 100 Years of Pentecostal and Charismatic Reneval, 1901-2001). Edited by Vinson Synan. Translated by Maciej Wilkosz. Kraków-Szczecin: Instytut Wydawniczy Compassion, pp. $213-49$.

Synan, Vinson. 2006b. Odnowa charyzmatyczna dociera do Kościołów historycznych. In Historia ruchu zielonoświątkowego i odnowy charyzmatycznej (orig. The century of the Holy Spirit: 100 Years of Pentecostal and Charismatic Reneval, 1901-2001). Edited by Vinson Synan. Translated by Maciej Wilkosz. Kraków-Szczecin: Instytut Wydawniczy Compassion, pp. 179-212.

Synan, Vinson. 2006c. Stulecie zielonoświątkowe: Zarys ogólny. In Historia ruchu zielonoświątkowego i odnowy charyzmatycznej (orig. The century of the Holy Spirit: 100 Years of Pentecostal and Charismatic Reneval, 1901-2001). Edited by Vinson Synan. Translated by Maciej Wilkosz. Kraków-Szczecin: Instytut Wydawniczy Compassion, pp. 13-26.

The Bishops of the Netherlands. 1988. Pastoral Statement on the Roman Catholic Charismatic Renewal in The Netherlands. Available online: http:/ / www.iccrs.org/_files/files/Resources\%20English/DOCUMENT-CCR_Bishops-Netherlands_1988_En.pdf (accessed on 3 June 2019).

The Canadian Conference of Catholic Bishops. 2003. Statement on the Charismatic Renewal. The Charismatic Renewal in Canada 2003. Available online: http://www.iccrs.org/_files/files/Resources\%20English/STATEMENT-CCR_Bishops-Canada_2003_En.pdf (accessed on 25 February 2018).

The Council of Trent. 1546. Decree Concerning Original Sin. Available online: https://www.documentacatholicaomnia.eu/03d/1545-1 545,_Concilium_Tridentinum,_Canons_And_Decrees,_EN.pdf (accessed on 30 January 2021).

The Holy See. 1986. Sects of New Religious Movements: A Pastoral Challenge. Available online: https:/ /www.ewtn.com/catholicism/ library / sects-of-new-religious-movements-a-pastoral-challenge-11325 (accessed on 15 March 2021).

The New Zealand Catholic Bishops' Conference. 1981. A Letter to Our Fellow Priests from the Bishops of New Zeland. Available online: http://www.iccrs.org/_files / files/Resources\%20English/LETTER_Bishops-New-Zealand_1981_En.pdf (accessed on 20 February 2018). 
The United States Conference of Catholic Bishops. 1997. Grace for the New Springtime. A Statement from the United States Catholic Conference of Bishops on the Charismatic Renewal. Available online: http://www.iccrs.org/_files/files/Resources\%20English/ STATEMENT-CCR_Bishops-USA_1997_En.pdf (accessed on 3 June 2019).

Theologischen Ausschuss der Charismatischen Erneuerung in der Katholischen Kirche. 2007. Der Geist macht lebendig. Theologische und pastorale Grundlagen der Charismatischen Erneunerung in der Katholischen Kirche Deutschlands. Nördlingen: Druckerei Steinmeier. 